\title{
Effects of different supplements on splanchnic oxygen consumption and net fluxes of nutrients in sheep consuming bromegrass (Bromus inermis) hay ad libitum
}

\author{
BY A. L. GOETSCH* \\ Department of Animal Sciences, University of Arkansas, Fayetteville, Arkansas 72701, USA \\ AND C. L. FERRELL AND H. C. FREETLY \\ Roman L. Hruska Meat Animal Research Center, Agricultural Research Service, USDA, \\ Clay Center, Nebraska 68933, USA
}

(Received 12 May 1993 - Revised 4 February 1994 - Accepted 2 March 1994)

\begin{abstract}
Fifteen sheep $(53 \mathrm{~kg})$, with catheters in a bepatic vein, the portal vein and a mesenteric vein and artery, were offered a bromegrass (Bromus inermis) hay (104 g crude protein (CP), $700 \mathrm{~g}$ neutral-detergent fibre and $65 \mathrm{~g}$ acid-detergent lignin/kg dry matter (DM)) ad lib. with different supplements to determine the effects on net flux of oxygen and nutrients across the portal-drained viscera (PDV) and liver. The sheep were unsupplemented (Control) or received $5 \mathrm{~g} \mathrm{DM} / \mathrm{kg}$ body weight (BW) of ground maize (M), $7 \mathrm{~g}$ $\mathrm{DM} / \mathrm{kg} \mathrm{BW}$ of soya-bean hulls $(\mathrm{H})$ or $0.73 \mathrm{~g} \mathrm{DM} / \mathrm{kg} \mathrm{BW}$ of a mix of feedstuffs high in rumenundegradable protein (P). Apparent digestible energy (DE) intakes were 5.3, 10.4, 10.6 and 6.7 (SE 0.74) MJ/d and apparent digestible CP intakes were 37, 50, 79 and 68 (SE 4.3) g/d for Control, $M, H$ and $P$ treatments respectively. Splanchnic tissue oxygen consumption rates were $0.23,0.32,0.30$ and 0.27 (SE 0.054) $\mathrm{mol} / \mathrm{h}$, and oxidative metabolism accounted for 0.46, 0.31, 0.33 and 0.47 (SE 0.051) of DE intakes for Control, $M, H$ and $P$ treatments respectively. Supplements increased $(P<0.05)$ release of $\alpha$-amino nitrogen (AAN) by the PDV $(4 \cdot 2,17.5,19.6$ and $18.1 \mathrm{mmol} / \mathrm{h}$ for Control, $M, H$ and $P$ treatments respectively). Splanchnic net flux of AAN was not affected by supplement treatments. Hepatic release of urea- $\mathrm{N}$ was increased $(P<0.05)$ by supplement treatments $(27,40,46$ and $44 \mathrm{mmol} / \mathrm{h}$ for Control, $M, H$ and $P$ respectively); the $P$ treatment increased $(P<0.05)$ and the $H$ treatment tended $(P=0 \cdot 10)$ to increase splanchnic release of urea-N $(7,10,20$ and $27 \mathrm{mmol} / \mathrm{h}$ for Control, $M, H$ and $P$ treatments respectively). Net flux of glucose across the PDV was $-4.6,1.4,-5.6$ and -7.2 (SE 1.65$) \mathrm{mmol} / \mathrm{h}$ for Control, $M, H$ and $P$ treatments respectively. Hepatic glucose released averaged 23 (SE 2.0) $\mathrm{mmol} / \mathrm{h}$ and was not affected by treatment. Treatments $M$ and $H$ increased $(P<0.05) P D V$ release of propionate compared with the Control treatment $(4 \cdot 5,15 \cdot 5,16 \cdot 8$ and $7 \cdot 7 \mathrm{mmol} / \mathrm{h}$ for Control, $M, H$ and $P$ treatments respectively). Release of acetate by the PDV was 43, 97, 118 and 67 (SE 23.9) $\mathrm{mmol} / \mathrm{h}$ for Control, $M, H$ and $P$ treatments respectively. In summary, different supplements of low-quality grass did not increase the efficiency of $\mathbf{N}$ metabolism by splanchnic tissues. Treatment $\mathbf{P}$ had little effect on net flux across splanchnic tissues of glucose, L-lactate, $\beta$-hydroxybutyrate and volatile fatty acids (VFA). Overall, treatments $M$ and $H$ had similar effects on splanchnic net fluxes of VFA and L-lactate whereas butyrate and $\beta$-hydroxybutyrate releases by the PDV were increased by treatment $M$.
\end{abstract}

Bromus inermis: Splanchnic metabolism: Forage: Dietary supplement

Digestible energy (DE) intake and the array of metabolites available to splanchnic tissues affect energy consumption by splanchnic tissues and nutrients available for metabolism by extra-splanchnic tissues (Ferrell et al. 1986; Johnson et al. 1990; Demigné et al. 1991; van der Walt, 1993). A wide variety of feedstuffs is available to supplement forages. Feedstuffs

* For reprints. 
high in starch or degradable fibre both increase total digestible energy intakes to extents determined by changes in feed intake and digestibility. High-starch supplements generally increase energy intake, propionate production and intestinal glucose absorption whereas feedstuffs high in rumen-degradable fibre increase energy intake without markedly altering rumen volatile fatty acid (VFA) ratios (Highfill et al. 1987; Grigsby et al. 1993). Intestinal amino acid absorption is increased by energy supplements and rumen-undegradable protein sources. However, rumen-undegradable protein sources do not markedly affect forage intake, energy absorption or VFA proportions with forages moderate to high in $\mathrm{N}$ concentration (McCollum \& Horn, 1990). Effects of supplements on portal-drained viscera (PDV) ammonia release and urea uptake and on hepatic urea release and consumption of amino acids are likely to depend largely on relationships between ruminal degradation of nitrogenous compounds and carbohydrates, and may affect energy consumption and efficiency of metabolism by splanchnic tissues. The objectives of this study were to compare effects of supplemental feedstuffs high in starch, rumen-degradable fibre or rumenundegradable protein on net fluxes of oxygen and nutrients across the PDV and liver of sheep consuming bromegrass (Bromus inermis) hay ad lib.

\section{MATERIALS AND METHODS}

Fifteen Romanov $\times$ Composite III (Meat Animal Research Center; 1/4 Suffolk, 1/4 Hampshire and 1.2 Columbia) castrated male sheep (approximately 11 months old) were surgically fitted with chronic indwelling catheters in a hepatic vein, the portal vein and a mesenteric vein and artery (Ferrell et al. 1992). Catheter tip lengths were $64 \mathrm{~mm}$ for hepatic and portal veins and $380 \mathrm{~mm}$ for mesenteric catheters. Catheters were filled with a heparinized saline $(9 \mathrm{~g} \mathrm{NaCl} / \mathrm{l})$ solution $(100 \mathrm{U} / \mathrm{ml})$ at surgery and between sampling periods. Some catheters were non-patent at sampling and erroneous portal blood flows occurred for some lambs. Post-mortem examination revealed that such flows resulted from the mesenteric vein catheter residing near the entry point of the portal catheter, presumably resulting in incomplete marker mixing at the tip of the portal catheter. Thus, complete data sets were obtained for seven sheep (one from the control group and two from each of the supplement-treatment groups). The sheep began the experiment 16 to $20 \mathrm{~d}$ after surgery (53 (SE 1.1) kg body weight (BW)), being individually maintained in $1.2 \times 1.2 \mathrm{~m}$ slatted floor pens with free access to water.

Sheep were randomly allocated to four treatments: no supplementation (Control); $5 \mathrm{~g}$ $\mathrm{DM} / \mathrm{kg} \mathrm{BW}$ of ground maize (M); $7 \mathrm{~g} \mathrm{DM} / \mathrm{kg} \mathrm{BW}$ of soya-bean hulls $(\mathrm{H})$; or $0.73 \mathrm{~g}$ $\mathrm{DM} / \mathrm{kg} \mathrm{BW}$ of a mix of feedstuffs high in rumen-undegradable protein ( $\mathrm{P}$; see Table 1$)$. Four wethers were subjected to treatments Control, $M$ and $H$, and three wethers received the $\mathbf{P}$ treatment. $\mathbf{M}$ and $H$ supplements were fed to provide similar quantities of $D E$ (National Research Council, 1984). The P supplement consisted of $466 \mathrm{~g}$ maize-gluten meal, $267 \mathrm{~g}$ feather meal and $267 \mathrm{~g}$ blood meal $/ \mathrm{kg}$ DM, providing an amount of supplemental crude protein (CP) intermediate to that of $\mathbf{M}$ and $\mathbf{H}$ treatments. All sheep were offered coarsely chopped hay, predominantly of bromegrass (no flowering heads), ad lib. (120\% of previous day's consumption; see Table 1). Supplements were given at 07.30 and 15.30 hours on days 1 to 16 and at 07.30 and 19.30 hours on days 17 to 28 in two equal meals. Supplements were consumed in less than $15 \mathrm{~min}$; hay was offered after supplement ingestion. At each meal, $5 \mathrm{~g}$ of a $\mathrm{NaCl}$-trace mineral mixture $(988: 12, \mathrm{w} / \mathrm{w})$ containing $(\mathrm{mg} / \mathrm{g})$ : calcium 148, zinc 120 , manganese 80 , iron 10 , iodine 2 and cobalt 1 , was sprinkled on the hay.

Forage was consumed ad lib. and set quantities of supplement were given in two meals so that conditions would resemble those of common production systems. Similar forage is 
Table 1. Composition of feeds $(\mathrm{g} / \mathrm{kg}$ dry matter $(D M))$

\begin{tabular}{lcccc}
\hline Item & $\begin{array}{c}\text { Bromegrass } \\
\text { (Bromus inermis) }\end{array}$ & Ground maize & Soya-bean hulls & Protein meals \\
\hline Ash & 116 & 16 & 60 & 18 \\
Crude protein & 104 & 81 & 167 & 808 \\
Gross energy (MJ/kg DM) & $18 \cdot 1$ & $18 \cdot 6$ & $18 \cdot 7$ & $24 \cdot 3$ \\
Neutral-detergent fibre & 695 & 125 & 554 & 265 \\
Acid-detergent fibre & 452 & 21 & 395 & 107 \\
Acid-detergent lignin & 65 & 8 & 21 & 72 \\
Cellulose & 345 & 13 & 382 & 52 \\
Hemicellulose & 243 & 104 & 159 & 158 \\
\hline
\end{tabular}

usually consumed ad lib. as pasture herbage or as hay offered to ruminants on dormant pasture, and set quantities rather than constant dietary proportions of supplements typically are given. Levels of supplementation in our study were moderate, sufficient for a moderate rate of BW gain by growing animals and for maintenance or a slight increase in BW of gestating ruminants.

Composite feed samples were constructed by daily sampling (days 18 to 28). Faeces were collected in canvas bags on days 21 to 27 ( $4 \mathrm{~d} /$ sheep), with collections starting daily (days 21 to 24$)$ for three or four sheep. Composites were frozen after sampling $(100 \mathrm{~g} / \mathrm{kg})$. Refusals were sampled $(100 \mathrm{~g} / \mathrm{kg})$ and composites were formed over a $7 \mathrm{~d}$ period $(3 \mathrm{~d}$ before and during faecal collection). On the last $4 \mathrm{~d}$ of the period and on the morning of faecal bag removal, sheep were placed in metabolism cages, with feed and water availability maintained. A priming dose (15 ml) of $p$-amino hippuric acid (PAH; 0.15 M) was given at $2.5 \mathrm{~h}$ post-feeding, followed by a constant infusion $(0.8 \mathrm{ml} / \mathrm{min})$ of $\mathrm{PAH}$ into the mesenteric vein catheter for $6.5 \mathrm{~h}(2.5$ to $9 \mathrm{~h}$ post-feeding). BW was determined immediately after sampling.

Blood samples (1 and $10 \mathrm{ml}$ ) were withdrawn from portal and hepatic venous and mesenteric arterial catheters hourly from 3 to $9 \mathrm{~h}$ post-feeding into heparinized syringes, and placed on ice. Oxygen saturation and haemoglobin concentration were determined immediately with the $1 \mathrm{ml}$ sample using a Hemoximeter (OSM 2; Radiometer Corporation, Copenhagen, Denmark); oxygen concentration was calculated as described by Eisemann \& Nienaber (1990). Blood from a $1 \mathrm{ml}$ sample was analysed for glucose with a membraneimmobilized enzyme system involving glucose oxidase ( $E C$ 1.1.3.4; Model 27, Yellow Springs Instrument Co., Yellow Springs, OH, USA). On the day of sampling, a $1 \mathrm{ml}$ portion of the $10 \mathrm{ml}$ sample was diluted with deionized water $(3 \mathrm{ml})$ and subjected to automated procedures (Technicon Industrial Systems, Tarrytown, NY, USA) for PAH, $\mathrm{NH}_{3}-\mathrm{N}$, urea- $\mathrm{N}$ and $\alpha$-amino nitrogen (AAN), as described by Eisemann \& Nienaber (1990). Blood flow for each time was calculated as described by Eisemann \& Nienaber (1990). The PAH procedure did not include an acid hydrolysis step; thus, PAH concentration may have been slightly underestimated due to the presence of $N$-acetyl forms. However, the potential error appears small because the hepatic arterial:venous blood flow ratio (Table 2) was similar to that in other studies (van der Walt, 1993).

Remaining blood from the $10 \mathrm{ml}$ sample was frozen. Later, these samples were allowed to thaw and were composited by volume within-animal and across time and vessel. After deproteinization with $\mathrm{Ba}(\mathrm{OH})_{2}$ and $\mathrm{ZnSO}_{4}$ (Yen et al. 1991), concentrations of VFA (as described by Yen et al. 1991), L-lactate (membrane-immobilized enzyme system involving lactate oxidase (EC 1.1.3.2; Model 27, Yellow Springs Instrument Co.) and D- $\beta$ - 
Table 2. Whole-blood flow, and oxygen and $\alpha$-amino, urea and ammonia nitrogen measures in sheep consuming bromegrass (Bromus inermis) ad lib. with different supplements*

(Mean values and pooled standard error for three observations per treatment)

\begin{tabular}{|c|c|c|c|c|c|}
\hline \multirow[b]{2}{*}{ Item } & \multicolumn{4}{|c|}{ Treatment } & \multirow[b]{2}{*}{ SE } \\
\hline & Control & Maize & $\begin{array}{c}\text { Soya-bean } \\
\text { hulls }\end{array}$ & $\begin{array}{l}\text { Protein } \\
\text { meals }\end{array}$ & \\
\hline \multicolumn{6}{|l|}{ Blood flow $(1 / h)$} \\
\hline Portal vein & 89 & 120 & 120 & 101 & $25 \cdot 4$ \\
\hline Hepatic vein & 109 & 143 & 139 & 118 & $26 \cdot 1$ \\
\hline Hepatic artery & 20 & 23 & 19 & 17 & $7 \cdot 0$ \\
\hline \multicolumn{6}{|l|}{ Oxygen } \\
\hline \multicolumn{6}{|l|}{ Concentration $(\mathrm{mmol} / \mathrm{l})$} \\
\hline Portal vein & $4 \cdot 24$ & $4 \cdot 17$ & 4.64 & 3.98 & 0.394 \\
\hline Hepatic vein & 3.48 & $3 \cdot 28$ & 3.84 & 3.07 & 0.393 \\
\hline Artery & $5 \cdot 56$ & 5.52 & 6.03 & $5 \cdot 38$ & 0.423 \\
\hline \multicolumn{6}{|l|}{ Consumption (mmol/h) } \\
\hline Portal-drained viscera & 119 & 164 & 163 & 141 & 34.8 \\
\hline Liver & 109 & 156 & 132 & 131 & 22.5 \\
\hline Splanchnic & 228 & 320 & 295 & 271 & $53 \cdot 5$ \\
\hline \multicolumn{6}{|l|}{$\alpha$-Amino nitrogen } \\
\hline \multicolumn{6}{|l|}{ Concentration $(\mathrm{mmol} / \mathrm{l})$} \\
\hline Portal vein & 4.59 & $4 \cdot 33$ & $4 \cdot 10$ & 4.59 & 0.350 \\
\hline Hepatic vein & 4.45 & $4 \cdot 20$ & 3.92 & 4.38 & 0.355 \\
\hline Artery & 4.51 & $4 \cdot 20$ & 3.93 & 4.41 & 0.353 \\
\hline \multicolumn{6}{|l|}{ Net flux $(\mathrm{mmol} / \mathrm{h})$} \\
\hline Portal-drained viscera & $7 \cdot 2$ & $17 \cdot 5$ & $19 \cdot 6$ & $18 \cdot 1$ & $2 \cdot 98$ \\
\hline Liver & $-13 \cdot 2$ & $-15 \cdot 0$ & $-22 \cdot 1$ & $-21 \cdot 7$ & 5.60 \\
\hline Splanchnic & -6.0 & $2 \cdot 4$ & $-2 \cdot 5$ & $-3 \cdot 5$ & $3 \cdot 22$ \\
\hline \multicolumn{6}{|l|}{ Urea nitrogen } \\
\hline \multicolumn{6}{|l|}{ Concentration $(\mathrm{mmol} / \mathrm{l})$} \\
\hline Portal vein & $8 \cdot 34$ & $6 \cdot 63$ & 9.09 & 10.93 & 0.785 \\
\hline Hepatic vein & 8.57 & 6.94 & $9 \cdot 46$ & 11.33 & 0.797 \\
\hline Artery & 8.49 & 6.85 & $9 \cdot 32$ & 11.09 & 0.781 \\
\hline \multicolumn{6}{|l|}{ Net flux $(\mathrm{mmol} / \mathrm{h})$} \\
\hline Portal-drained viscera & $-13 \cdot 5$ & $-30 \cdot 4$ & $-26 \cdot 7$ & $-17 \cdot 3$ & 8.25 \\
\hline Liver & $26 \cdot 7$ & $40 \cdot 2$ & $46 \cdot 3$ & $44 \cdot 1$ & $5 \cdot 20$ \\
\hline Splanchnic & $7 \cdot 3$ & 9.8 & $19 \cdot 6$ & $26 \cdot 9$ & $4 \cdot 38$ \\
\hline \multicolumn{6}{|l|}{ Ammonia nitrogen } \\
\hline \multicolumn{6}{|l|}{ Concentration $(\mathrm{mmol} / \mathrm{l})$} \\
\hline Portal vein & 0.404 & 0.430 & 0.486 & 0.454 & 0.0352 \\
\hline Hepatic vein & 0.278 & 0.274 & 0.296 & 0.254 & 0.0324 \\
\hline Artery & 0.278 & $0 \cdot 274$ & 0.294 & 0.266 & 0.0298 \\
\hline \multicolumn{6}{|l|}{ Net flux $(\mathrm{mmol} / \mathrm{h})$} \\
\hline Portal-drained viscera & 10.6 & $18 \cdot 8$ & $23 \cdot 4$ & $19 \cdot 1$ & 3.73 \\
\hline Liver & $-10 \cdot 5$ & $-19 \cdot 2$ & $-23 \cdot 4$ & $-20 \cdot 4$ & $4 \cdot 14$ \\
\hline Splanchnic & 0.2 & -0.4 & 0.0 & $-1 \cdot 3$ & 0.77 \\
\hline
\end{tabular}

* For details of diets and procedures, see Table 1 and pp. 703-705.

hydroxybutyrate (BHBA; Williamson \& Mellanby, 1974) were determined. Blood flows and constituent concentrations were averaged over time, and net metabolite fluxes were calculated as described by Burrin et al. (1991).

Faecal composites were dried at $55^{\circ}$, allowed to air-equilibrate and ground to pass a $1 \mathrm{~mm}$ screen. Feed and refusal samples were ground to pass a $1 \mathrm{~mm}$ screen. Feed, refusal and faecal samples were analysed for DM, ash, Kjeldahl N, gross energy (Association of 
Official Analytical Chemists, 1984), neutral-detergent fibre (without $\mathrm{Na}_{2} \mathrm{SO}_{3}$ or decalin), acid-detergent fibre (nonsequential) and acid-detergent lignin (Goering \& Van Soest, 1970). Amylase (EC 3.2.1.1) was used for neutral-detergent fibre analysis of concentrates, cellulose was estimated as loss in weight upon $\mathrm{H}_{2} \mathrm{SO}_{4}$ treatment and hemicellulose was the difference between neutral- and acid-detergent fibre fractions. Feed intake on the $2 \mathrm{~d}$ before and during faecal collections ( $6 \mathrm{~d}$ total) was averaged across days and used to calculate digestibilities. The mean of feed intake on the day before and the day of blood sampling was used to evaluate relationships of feed intake and net fluxes of oxygen and nutrients.

At $28 \mathrm{~d}$ after the first period (Period 1), eight sheep (54 (SE 1.4) kg BW) which previously had patent catheters and appeared to yield reasonable portal blood flows were allocated to different treatments (two per treatment) and subjected to the same procedures. Period 2 lasted $26 \mathrm{~d}$, with blood sampling on the last $2 \mathrm{~d}$ of the period. Complete data sets were obtained for five sheep (two from the Control group and one from each of the supplementtreatment group).

Data were analysed by the general linear models procedure of Statistical Analysis Systems (1985) with period, treatment and the treatment $\times$ period interaction in the model. Single degree of freedom contrasts were used to compare $\mathbf{M}, \mathbf{H}$ or $\mathbf{P}$ with the Control treatment. Only data sets with complete sets of observations were used.

\section{RESULTS}

Total DM intakes were 0.66, 1.01, 1.00 and 0.69 (SE 0.046) $\mathrm{kg} / \mathrm{d}$, DE intakes were 5.3, 10.4, 10.6 and 6.7 (SE 0.74) MJ/d, and digestible CP intakes were 37, 50, 79 and 68 (SE 4.3) g/d for Control, $\mathbf{M}, \mathrm{H}$ and $\mathrm{P}$ treatments respectively. Blood flows and oxygen concentrations and consumption rates were not altered by supplement treatments (Table 2). All supplements increased $(P<0.05)$ the release of AAN by the splanchnic bed compared with the Control treatment, but hepatic and splanchnic net fluxes were not affected by treatment. Urea-N uptake by the PDV was similar across treatments, but $\mathbf{M}, \mathbf{H}$ and $\mathbf{P}$ treatments increased $(P<0.05)$ urea-N released by the liver. Urea-N released by the PDV was increased by $\mathrm{P}(P<0.05)$ and tended $(P=0.10)$ to be increased by $\mathrm{H}$. Supplementation with $\mathrm{H}$ increased $(P<0.05) \mathrm{NH}_{3}-\mathrm{N}$ release by the PDV and tended $(P=0.07)$ to increase hepatic uptake.

Concentrations of glucose (Table 3 ) in portal and hepatic venous and arterial blood were higher $(P<0.05)$ in treatments $\mathrm{M}$ and $\mathrm{H}$ compared with Control and also tended $(P=$ $0 \cdot 10)$ to be higher in treatment $P$. Treatment $M$ had a higher $(P<0.05)$ net flux of glucose across the PDV; however, neither hepatic nor splanchnic release was markedly affected by treatment. The PDV was a net utilizer of glucose and the quantity taken up was relatively constant for Control, $H$ and $P$ treatments. Hepatic release of glucose (20 (SE 2.3) mmol/h) resulted in average splanchnic release of 16 (SE $2 \cdot 7) \mathrm{mmol} / \mathrm{h}$. Both treatments $\mathrm{M}$ and $\mathbf{H}$ increased $(P<0.05)$ the concentration of propionate in portal venous blood compared with the Control whereas the concentration in hepatic venous blood was increased $(P<0.05)$ by treatment $\mathrm{H}$ but not by treatment $\mathrm{M}$. Treatments $\mathrm{M}$ and $\mathrm{H}$ similarly increased $(P<0.05)$ propionate released by the PDV and splanchnic tissues and taken up by the liver compared with the Control. L-Lactate concentrations were not affected by treatment; hepatic uptake of L-lactate tended $(P=0 \cdot 10)$ to be lower for treatment $\mathrm{H}$ than for the Control.

Concentrations of acetate in portal and hepatic venous blood were higher in treatment $H$ than in the Control $(P<0.05$; Table 4). PDV release of acetate tended $(P=0.07)$ to be higher in treatment $\mathrm{H}$. Concentrations of butyrate in portal and hepatic venous blood were elevated $(P<0.05)$ by treatments $\mathrm{M}$ and $\mathrm{H}$. Compared with the Control treatment, treatment $M$ enhanced $(P<0.05)$ PDV release and hepatic uptake of butyrate and tended $(P=0 \cdot 10)$ to increase splanchnic release. Treatment $H$ tended to increase PDV release of 
Table 3. Whole-blood glucose, propionate and L-lactate measures in sheep consuming bromegrass (Bromus inermis) ad lib. with different supplements*

(Mean values and pooled standard errors for three observations per treatment)

\begin{tabular}{|c|c|c|c|c|c|}
\hline \multirow[b]{2}{*}{ Item } & \multicolumn{4}{|c|}{ Treatment } & \multirow[b]{2}{*}{ SE } \\
\hline & Control & Maize & $\begin{array}{l}\text { Soya-bean } \\
\text { hulls }\end{array}$ & $\begin{array}{l}\text { Protein } \\
\text { meals }\end{array}$ & \\
\hline \multicolumn{6}{|l|}{ Glucose } \\
\hline \multicolumn{6}{|l|}{ Concentration $(\mathrm{mmol} / \mathrm{l})$} \\
\hline Portal vein & $2 \cdot 72$ & $3 \cdot 11$ & 3.05 & $2 \cdot 92$ & 0.073 \\
\hline Hepatic vein & 2.89 & 3.26 & $3 \cdot 20$ & $3 \cdot 10$ & 0.077 \\
\hline Artery & $2 \cdot 77$ & 3.08 & $3 \cdot 11$ & 2.99 & 0.080 \\
\hline \multicolumn{6}{|l|}{ Net flux $(\mathrm{mmol} / \mathrm{h})$} \\
\hline Portal-drained viscera & $-4 \cdot 6$ & 1.4 & $-5 \cdot 6$ & $-7 \cdot 2$ & $1 \cdot 65$ \\
\hline Liver & $18 \cdot 3$ & $23 \cdot 5$ & 17.2 & 19.4 & $5 \cdot 12$ \\
\hline Splanchnic & 13.7 & 24.8 & $11 \cdot 7$ & $12 \cdot 2$ & 4.98 \\
\hline \multicolumn{6}{|l|}{ Propionate } \\
\hline \multicolumn{6}{|l|}{ Concentration (mmol/l) } \\
\hline Portal vein & 0.082 & 0.175 & $0 \cdot 180$ & 0.090 & 0.0215 \\
\hline Hepatic vein & 0.028 & 0.046 & 0.061 & 0.026 & 0.0079 \\
\hline Artery & 0.026 & 0.029 & 0.032 & 0.015 & 0.0053 \\
\hline \multicolumn{6}{|l|}{ Net flux $(\mathrm{mmol} / \mathrm{h})$} \\
\hline Portal-drained viscera & 4.5 & $15 \cdot 5$ & $16 \cdot 5$ & $7 \cdot 7$ & $1 \cdot 14$ \\
\hline Liver & -4.5 & $-13 \cdot 0$ & $-13 \cdot 1$ & $-6 \cdot 4$ & $1 \cdot 15$ \\
\hline Splanchnic & 0.0 & 2.5 & 3.6 & 1.3 & 0.64 \\
\hline \multicolumn{6}{|l|}{ L-Lactate } \\
\hline \multicolumn{6}{|l|}{ Concentration $(\mathrm{mmol} / \mathrm{l})$} \\
\hline Portal vein & 1.45 & 1.51 & 1.58 & 1.48 & 0.103 \\
\hline Hepatic vein & $1 \cdot 12$ & 1.31 & 1.41 & 1.21 & 0.119 \\
\hline Artery & 1.26 & 1.38 & $1 \cdot 48$ & 1.36 & $0 \cdot 107$ \\
\hline \multicolumn{6}{|l|}{ Net flux $(\mathrm{mmol} / \mathrm{h})$} \\
\hline Portal-drained viscera & 18.5 & $15 \cdot 6$ & 10.9 & $11 \cdot 3$ & 3.58 \\
\hline Liver & -340 & $-24 \cdot 4$ & $-13 \cdot 1$ & $-27 \cdot 7$ & 7.48 \\
\hline Splanchnic & -15.4 & -8.9 & $-2 \cdot 2$ & $-16 \cdot 4$ & 6.38 \\
\hline
\end{tabular}

* For details of diets and procedures, see Table 1 and pp. 703-705.

butyrate and to decrease $(P=0 \cdot 10)$ hepatic uptake. Treatment $\mathrm{M}$ tended $(P=0.06)$ to increase BHBA release, although splanchnic release of BHBA was not affected by treatment.

\section{DISCUSSION}

Samples were taken 3 to $9 \mathrm{~h}$ post-feeding so that periods following meals with elevated blood flow and thereafter when flow declined and stabilized at pre-feeding levels would be represented (Mineo et al. 1991). It is probable that effects of time post-feeding on blood flow and nutrient fluxes were similar for treatments $M$ and $H$. In mature beef cattle consuming grass hay alone or supplemented with $\mathrm{M}$ at $210 \mathrm{~g} / \mathrm{kg}$ diet or $\mathrm{H}$ at $260 \mathrm{~g} / \mathrm{kg}$ diet, neither effects of time post-feeding nor interactions between time and supplement treatment were observed in rumen pH (Galloway et al. 1993). Chase \& Hibberd (1987) and Martin \& Hibberd (1990) supplemented low-quality forages once daily with different levels of $\mathbf{M}$ or $\mathrm{H}$ and observed patterns of depression in rumen $\mathrm{pH}$ with $\mathrm{M}$ or $\mathrm{H}$ at the same postfeeding sampling times as in this study. Although varying slightly with level of supplementation, $\mathrm{pH}$ generally rose at $9 \mathrm{~h}$ post-feeding for $\mathbf{M}$ and $\mathbf{H}$ (Chase \& Hibberd, 1987; Martin \& Hibberd, 1990). Because of the low rumen-degradability of the P 
Table 4. Whole-blood acetate, butyrate and $\beta$-hydroxybutyrate measures in sheep consuming bromegrass (Bromus inermis) ad lib. with different supplements*

(Mean values and pooled standard errors for three observations per treatment)

\begin{tabular}{|c|c|c|c|c|c|}
\hline \multirow[b]{2}{*}{ Item } & \multicolumn{4}{|c|}{ Treatment } & \multirow[b]{2}{*}{ SE } \\
\hline & Control & Maize & $\begin{array}{c}\text { Soya-bean } \\
\text { hulls }\end{array}$ & $\begin{array}{l}\text { Protein } \\
\text { meals }\end{array}$ & \\
\hline \multicolumn{6}{|l|}{ Acetate } \\
\hline \multicolumn{6}{|l|}{ Concentration (mmol/l) } \\
\hline Portal vein & $2 \cdot 58$ & $3 \cdot 10$ & 3.47 & $2 \cdot 65$ & 0.254 \\
\hline Hepatic vein & 2.57 & $2 \cdot 91$ & $3 \cdot 51$ & $2 \cdot 32$ & 0.254 \\
\hline Artery & 2.07 & $2 \cdot 16$ & $2 \cdot 28$ & 1.98 & 0.287 \\
\hline \multicolumn{6}{|l|}{ Consumption (mmol/h) } \\
\hline Portal-drained viscera & $43 \cdot 4$ & $97 \cdot 3$ & $118 \cdot 4$ & $67 \cdot 3$ & 23.92 \\
\hline Liver & 6.9 & $16-1$ & $18 \cdot 1$ & -27.9 & $21 \cdot 72$ \\
\hline Splanchnic & $50 \cdot 3$ & 113.4 & $136 \cdot 6$ & $39 \cdot 4$ & $41 \cdot 62$ \\
\hline \multicolumn{6}{|l|}{ Butyrate } \\
\hline \multicolumn{6}{|l|}{ Concentration $(\mathrm{mmol} / \mathrm{l})$} \\
\hline Portal vein & 0.004 & 0.026 & 0.021 & 0.009 & 0.0036 \\
\hline Hepatic vein & 0.003 & $0-013$ & 0.012 & 0.004 & 0.0027 \\
\hline Artery & 0.001 & 0.006 & 0.005 & 0.002 & 0.0005 \\
\hline \multicolumn{6}{|l|}{ Net flux $(\mathrm{mmol} / \mathrm{h})$} \\
\hline Portal-drained viscera & $0 \cdot 16$ & 2.67 & 1.83 & 0.72 & 0.610 \\
\hline Liver & 0.00 & $-1 \cdot 56$ & -1.05 & -0.43 & 0.385 \\
\hline Splanchnic & 0.16 & $1 \cdot 11$ & 0.78 & 0.29 & 0.345 \\
\hline \multicolumn{6}{|l|}{$\beta$-Hydroxybutyrate } \\
\hline \multicolumn{6}{|l|}{ Concentration (mmol/l) } \\
\hline Portal vein & 0.60 & 0.65 & 0.68 & 0.56 & 0.053 \\
\hline Hepatic vein & 0.74 & 0.70 & 0.72 & 0.67 & 0.059 \\
\hline Artery & 0.59 & 0.55 & 0.61 & 0.52 & 0.050 \\
\hline \multicolumn{6}{|l|}{ Net flux $(\mathrm{mmol} / \mathrm{h})$} \\
\hline Portal-drained viscera & $2 \cdot 0$ & $11 \cdot 8$ & $3 \cdot 2$ & 3.5 & 3.03 \\
\hline Liver & $15 \cdot 4$ & $8 \cdot 6$ & $14 \cdot 3$ & $14 \cdot 1$ & $3 \cdot 31$ \\
\hline Splanchnic & $17 \cdot 4$ & $20 \cdot 4$ & $17 \cdot 5$ & $17 \cdot 6$ & $3 \cdot 36$ \\
\hline
\end{tabular}

* For details of diets and procedures, see Table 1 and pp. 703-705.

supplement and its probable pattern of rumen outflow, the pattern of change with time in portal and hepatic blood flows should have been similar for $\mathbf{P}$ and Control treatments in this study. Furthermore, the moderate to low levels of supplementation, relatively low forage digestibility and ad lib. consumption of forage should have minimized change in blood flow and absorption with time post-feeding compared with higher levels of supplementation and consumption of set, restricted quantities of forage in discrete meals. Thus, the feeding and sampling regimens chosen should be adequate to describe $24 \mathrm{~h}$ blood flow and splanchnic net flux of nutrients for the purposes of this study. Additional support for our feeding and sampling regimens is provided by an experiment with lactating dairy cows consuming maize silage-concentrate $(60: 40)$ diets ad lib. with two meals daily (Reynolds et al. 1988). Net fluxes of acetate and propionate across the PDV, liver and total splanchnic tissues determined hourly for $12 \mathrm{~h}$ suggest that net flux calculated from samples taken at times used in our study would yield results similar to the average of measures at all times. 


\section{Blood flow}

Typically, portal and hepatic venous blood flows increase with increasing feed intake (Huntington \& Reynolds, 1987). However, blood flow in the period measured was not significantly affected by treatments $\mathrm{M}$ or $\mathrm{H}$ despite increases in daily DM and DE intakes, although the correlation between DM intake and portal blood flow approached significance $(r 0.47 ; P=0.12)$. Experiments in which relationships between splanchnic tissue blood flow and level of feed intake have been established generally have entailed relatively large differences in feed intake, less than ad lib. consumption and diets higher in digestibility than in our study (Johnson et al. 1990). High variability in blood flow and net flux of nutrients across the PDV and liver in our study suggest that with ad lib. consumption of a low-quality forage, a high number of observations may be necessary to determine significant differences between supplement treatments compared with restricted feeding of more digestible diets.

\section{Oxygen consumption}

Assuming 0.46 MJ of heat energy used per mol of oxygen consumed (McLean, 1972), energy consumption by splanchnic tissues was $0.48,0.34,0.30$ and 0.46 (SE 0.070) of DE intake for Control, $\mathbf{M}, \mathbf{H}$ and $\mathrm{P}$ treatments respectively. Splanchnic tissues provide a number of service functions for other tissues regardless of level of energy intake. With low energy intakes much of the energy consumed by splanchnic tissues is derived from endogenous substrates, such as free fatty acids and amino acids, rather than from absorbed nutrients. Although the effects of energy supplements on energy consumption were not significant, the effects on the array of metabolites, such as propionate, released by the PDV suggest that they may have led to an increased efficiency of hepatic metabolism.

\section{$\alpha$-Amino nitrogen}

Release of AAN by the PDV in the Control treatment did not differ from zero whilst supplement treatments resulted in marked increases. These findings probably reflect the moderate to low level of protein in the forage, extensive ruminal degradation of the forage protein and limited microbial protein synthesis without energy supplementation. Thus, differences between forage and supplement in level of rumen-undegradable protein and rumen-fermentable organic matter may have elicited change with supplementation, with the former being most important for $\mathrm{P}$ and the latter for $\mathrm{M}$ and $\mathrm{H}$. Release of AAN by the PDV was $0.25,0.42,0.34$ and 0.39 (SE 0.063) of $\mathrm{N}$ intake for control, $\mathrm{M}, \mathrm{H}$ and $\mathrm{P}$ respectively. The increased release of AAN by the PDV as a proportion of $N$ intake with supplement treatments suggests an increased proportion of ingested $\mathrm{N}$ captured in AAN released by the PDV.

These results suggest that feedstuffs high in starch, degradable fibre or rumenundegradable protein added to a low-quality forage can enhance PDV AAN release to the same degree. Furthermore, because apparently digestible $\mathrm{N}$ intake was considerably greater for $\mathrm{H}$ than for $\mathrm{M}$, change with energy supplements may be influenced relatively more by characteristics of rumen-fermentable organic matter than by rumen-degradable protein level.

Splanchnic AAN net flux did not differ from zero $(P>0 \cdot 10)$. Bergman \& Pell (1983) concluded that most amino acids released by the PDV are removed by the liver in adult sheep. Extensive hepatic amino acid metabolism relative to PDV release may be due to the relatively high stage of maturity of these sheep and to forage sources low in digestibility and moderate in $\mathrm{N}$ concentration. Also, PDV net flux of amino acids as assessed by AAN could have been slightly underestimated because of PDV release of peptides (Webb \& Bergman, 
1991) and carbon skeletons of amino acids (Lindsay, 1993), and potential binding of free amino acids in blood to larger substances such as albumin.

\section{Urea and ammonia nitrogen}

Because the $\mathrm{M}$ and $\mathrm{H}$ treatments would increase rumen-fermentable organic matter, it was anticipated that PDV $\mathrm{NH}_{3}-\mathrm{N}$ release would decline (Huntington \& Reynolds, 1987). That this did not occur may relate to a degree of asynchrony in ruminal availability of nitrogenous compounds with that of energy and carbon skeletons liberated in microbial fermentation with the supplement treatments, as well as the moderate concentration of $\mathbf{N}$ in the forage.

Hepatic and splanchnic tissue releases of urea- $\mathrm{N}$ imply that a considerable proportion of urea- $\mathrm{N}$ released by the liver was recycled to the gut in the Control, $\mathrm{M}$ and $\mathrm{H}$ treatments, with the quantity being lower for treatment $\mathrm{H}$ than $\mathrm{M}$. Greater intake of apparently digestible $\mathrm{N}$ for treatment $\mathrm{H}$ than for treatment $\mathrm{M}$ may have been responsible for greater urinary $\mathbf{N}$ excretion in treatment $\mathbf{H}$. Urinary excretion may have accounted for a greater proportion of urea- $\mathrm{N}$ released by the liver for treatment $\mathrm{P}$ than for other treatments. With treatment $P$, the absence of a marked change in DE intake coupled with an increased apparently digestible $\mathbf{N}$ intake presumably yielded a low potential for use of amino acids in peripheral protein synthesis relative to supply, with an ensuing high degree of deamination in the liver.

Overall, splanchnic tissue $N$ metabolism appeared least efficient in treatment $P$, with elevated $\mathrm{NH}_{3}-\mathrm{N}$ release by the PDV, high hepatic urea-N release and low recycling of urea$\mathrm{N}$ to the stomach. Treatments $\mathrm{M}$ and $\mathrm{H}$ increased hepatic urea- $\mathrm{N}$ release and urea-N uptake by the PDV similarly, although with treatment $\mathbf{H}$ a slightly lesser proportion of urea- $\mathrm{N}$ released by the liver was recycled to the gut because of a higher apparently digestible $\mathbf{N}$ intake.

Assuming $4.8 \mathrm{~mol}$ of ATP consumed per mol of urea synthesized in the liver (Burrin et al. 1991), energy consumed for ureagenesis was $0.11,0.21,0.25$ and 0.24 (SE 0.028 ) $\mathrm{MJ} / \mathrm{d}$ and $0 \cdot 10,0 \cdot 13,0 \cdot 17$ and $0 \cdot 17$ of total hepatic energy consumption for Control, $\mathbf{M}, \mathrm{H}$ and $P$ treatments respectively. Substantial increases for all supplement treatments in energy used in ureagenesis, and a similar PDV $\mathrm{NH}_{3}-\mathrm{N}$ release: $\mathrm{N}$ intake ratio among treatments, suggest potential to decrease liver energy consumption by improving synchrony of fermentation. Another factor which may have contributed to increased energy use in urea synthesis with supplementation was the feeding of a limited quantity of supplement at two discrete times daily. In addition, the low potential for lean tissue accretion of these sheep because of their stage of maturity may have minimized the potential for peripheral tissue protein accretion and demand for amino acids.

\section{Glucose}

Escape of starch from the rumen with treatment $M$ presumably was responsible for glucose release by the PDV. Treatment $M$ did not alter hepatic gluconeogenesis. Conversely, Janes et $a l$. $(1985 a, b)$ observed that the contribution of endogenous glucose to whole-body turnover was lower in sheep fed on a maize-based diet than in sheep consuming dried grass, although whole-body turnover was greater with the diet high in maize. It was suggested that the concentration of glucose in blood perfusing the liver affected hepatic gluconeogenesis (Janes et al. 1985a,b). Nonetheless, the level of glucose in portal venous blood in our experiment did not correlate with hepatic glucose release.

Supplementation with feedstuffs high in starch, degradable fibre or rumen-undegradable protein did not markedly alter hepatic release of glucose, although elevated PDV net flux 
in treatment $M$ tended to increase splanchnic tissue glucose release. Hence, improvements in ruminant performance which might occur under similar conditions in response to supplementation as with treatments $\mathbf{H}$ or $\mathbf{P}$ are unlikely to involve enhanced peripheral availability of glucose.

\section{Propionate and lactate}

Equivalent increases in PDV release of propionate for treatments $\mathrm{M}$ and $\mathrm{H}$ compared with the Control treatment imply that microbial propionate production was enhanced similarly or that extent of metabolism by ruminal epithelial cells differed. With ruminal propionate infusions, Gross et al. (1990) observed constant PDV metabolism of propionate in sheep regardless of infusion level. Conversely, Harmon et al. (1993) suggested that propionate oxidation in ruminal epithelium of growing beef steers consuming lucerne (Medicago sativa) hay was enhanced to spare arterial glucose from oxidation when monensin increased propionate availability.

Propionate typically is quantitatively the most important substrate for hepatic glucose synthesis (Bergman, 1990), most propionate extracted by the liver is used to form glucose (Weekes, 1991) and the proportion of synthesized glucose arising from propionate normally increases with propionate availability (Baird et al. 1980; Elliot, 1980). Weekes (1991) summarized estimates of endogenous glucose arising from propionate which ranged from 0.20 to 0.78 . Hepatic glucose release in our study was not altered by treatment regardless of change in PDV release of propionate. The maximal contribution of propionate released by the PDV to hepatic glucose release was $0.12,0.32,0.44$ and 0.19 (SE 0.056) for Control, $\mathrm{M}, \mathrm{H}$ and $\mathrm{P}$ treatments respectively. Because energy for gluconeogenesis is less with propionate than with other glucose precursors, such as lactate and amino acids (Demigné et al. 1991), energy supplements presumably decreased energy used by the liver for gluconeogenesis, with a slightly greater effect in treatment $H$. The reasons for the relatively low potential glucose synthesis from propionate in this experiment are unclear. Hepatic uptake of L-lactate was high relative to that of propionate, which suggests that a considerable proportion of glucose arose from lactate.

\section{Acetate, butyrate and $\beta$-hydroxybutyrate}

Though release of acetate by the PDV was not significantly elevated by treatment $\mathrm{M}$ or $\mathrm{H}$ compared with the Control treatment, DE intake was correlated with acetate release $(r 0.61 ; P<0.05)$. These results suggest that if energy supplements affect DE intake, PDV release of acetate rises concomitantly.

Increased PDV release of BHBA with treatment $M$ was most likely the result of enhanced microbial butyrate production and ruminal epithelial cell synthesis of BHBA. Butyrate and BHBA releases by the PDV were correlated $(r 0.66 ; P<0.05)$, presumably because of conversion of butyrate to BHBA in the ruminal epithelium. Increases in PDV release of butyrate with treatments $M$ and $H$ compared with the Control treatment may primarily relate to elevated rumen organic matter fermentation, although greater changes in PDV release of butyrate and BHBA for treatment $M$ than for treatment $H$ could entail a difference in ruminal fermentation pattern relating to an increased number of protozoa (Hall et al. 1990; Landis et al. 1990).

\section{Energy}

The sum of energy from amino acids (based on AAN), L-lactate, BHBA, acetate, propionate, butyrate and glucose released by the PDV (based on heat of combustion values

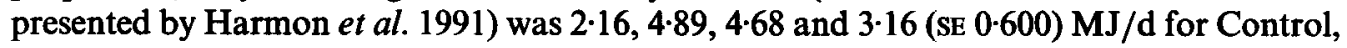
$\mathrm{M}, \mathrm{H}$ and $\mathrm{P}$ treatments respectively, representing $0.40,0.46,0.45$ and 0.49 (SE 0.065 ) of DE 
intake. Both treatments $\mathrm{M}$ and $\mathrm{H}(P<0.05)$ increased the quantity of energy released by the PDV compared with the Control treatment. VFA, primarily acetate, accounted for $0.48,0.58,0.67$ and 0.56 (SE 0.069) of PDV energy release for Control, M, H and P treatments respectively. Similarly, Harmon et al. (1993) observed that acetate, propionate and butyrate accounted for 0.56 and 0.59 of energy released by the PDV of steers fed on lucerne hay without or with monensin respectively.

All supplement treatments decreased energy released by the PDV in L-lactate $(0 \cdot 30,0 \cdot 09$, 0.08 and 0.12 (SE 0.033) for Control, $M, H$ and $P$ treatments respectively). The $P$ treatment also numerically increased energy released by the PDV in amino acids (based on AAN) compared with the Control treatment $(0 \cdot 17,0 \cdot 17,0.21$ and 0.27 (sE 0.037) for Control, $M$, $\mathrm{H}$ and $\mathrm{P}$ treatments).

The authors would like to express appreciation to B. Larsen, K. Corwin and S. Mohling for care and feeding of animals; and G. Rolls, D. Bedonie, B. Lee and J. Waechter for technical assistance.

\section{REFERENCES}

Association of Official Analytical Chemists (1984). Official Methods of Analysis, 14th ed. Washington, DC: AOAC.

Baird, G. D., Lomax, M. A., Symonds, H. W. \& Shaw, S. R. (1980). Net hepatic and splanchnic metabolism of lactate, pyruvate and propionate in dairy cows in vivo in relation to lactation and nutrient supply. Biochemical Journal 186, 47-57.

Bergman, E. N. (1990). Energy contributions of volatile fatty acids from the gastrointestinal tract in various species. Physiological Reviews 70, 567-590.

Bergman, E. N. \& Pell, J. M. (1984). Integration of amino acid metabolism in the ruminant. In Herbivore Nutrition in the Tropics and Subtropics, pp. 613-628 [F. M. C. Gilchrist and R. I. Mackie, editors]. Craighall, South Africa: The Science Press.

Burrin, D. G., Ferrell, C. L., Eisemann, J. H. \& Britton, R. A. (1991). Level of nutrition and splanchnic metabolite flux in young lambs. Journal of Animal Science 69, 1082-1091.

Chase, C. C. \& Hibberd, C. A. (1987). Utilization of low-quality native grass hay by beef cows fed increasing quantities of corn grain. Journal of Animal Science 65, 557-566.

Demigné, C., Yacoub, C., Morand, C. \& Rémésy, C. (1991). Interactions between propionate and amino acid metabolism in isolated sheep hepatocytes. British Journal of Nutrition 65, 301-317.

Eisemann, J. H. \& Nienaber, J. A. (1990). Tissue and whole-body oxygen uptake in fed and fasted steers. British Journal of Nutrition 64, 399-411.

Elliot, J. M. (1980). Propionate metabolism and vitamin $\mathbf{B}_{12}$. In Digestive Physiology and Metabolism in Ruminants, pp. 485-503 [Y. Ruckebusch and P. Thivend, editors]. Westport, CT: AVI Publishing Co.

Ferrell, C. L., Britton, R. A. \& Freetly, H. C. (1992). Chronic catheterization of hepatic and portal veins of sheep. In Handbook of Methods for Study of Reproductive Physiology in Domestic Animals, Section VIII A \& F [P. Dziuk and M. Wheeler, editors]. Urbana, IL: University of Illinois.

Ferrell, C. L., Koong, L. J. \& Nienaber, J. A. (1986). Effect of previous nutrition on body composition and maintenance energy costs of growing lambs. British Journal of Nutrition 56, 595-605.

Galloway, D. L. Sr, Goetsch, A. L., Forster, L. A. Jr, Patil, A. R., Sun, W. \& Johnson, Z. B. (1993). Feed intake and digestibility by cattle consuming bermudagrass or orchardgrass hay supplemented with soybean hulls and(or) corn. Journal of Animal Science 71, 3087-3095.

Goering, H. K. \& Van Soest, P. J. (1970). Forage Fiber Analyses. Apparatus, Reagents, Procedures and Some Applications. Agricultural Handbook no. 379. Washington, DC: ARS, USDA.

Grigsby, K. N., Kerley, M. S., Paterson, J. A. \& Weigel, J. C. (1993). Combinations of starch and digestible fiber in supplements for steers consuming a low-quality bromegrass hay diet. Journal of Animal Science 71, $1057-1064$.

Gross, K. L., Harmon, D. L., Minton, J. E. \& Avery, T. B. (1990). Effects of isoenergetic infusions of propionate and glucose on portal-drained visceral nutrient flux and concentrations of hormones in lambs maintained by total intragastric infusion. Journal of Animal Science 68, 2566-2574.

Hall, K. L., Goetsch, A. L., Landis, K. M., Forster, L. A. Jr \& Brake, A. C. (1990). Effects of a fat and ground maize supplement on feed intake and digestion by cattle consuming bermudagrass hay (Cynodon dactylon). Animal Feed Science and Technology 30, 275-288.

Harmon, D. L., Gross, K. L., Kreikemeier, K. K., Coffey, K. P., Avery, T. B. \& Klindt, J. (1991). Effects of feeding endophyte-infected fescue hay on portal and hepatic nutrient flux in steers. Journal of Animal Science 69, 1223-1231. 
Harmon, D. L., Kreikemeier, K. K. \& Gross, K. L. (1993). Influence of addition of monensin to an alfalfa hay diet on net portal and hepatic nutrient flux in steers. Journal of Animal Science 71, 218-225.

Highfill, B. D., Boggs, D. L., Amos, H. E. \& Crickman, J. G. (1987). Effects of high fiber energy supplements on fermentation characteristics and in vivo and in situ digestibilities of low quality fescue hay. Journal of Animal Science 65, 224-234.

Huntington, G. B. \& Reynolds, C. P. (1987). Oxygen consumption and metabolite flux of bovine portal-drained viscera and liver. Journal of Nutrition 117, 1167-1172.

Janes, A. N., Weekes, T. E. C. \& Armstrong, D. G. (1985a). Absorption and metabolism of glucose by the mesenteric-drained viscera of sheep fed on dried-grass or ground, maize-based diets. British Journal of Nutrition $54,449-458$.

Janes, A. N., Weekes, T. E. C. \& Armstrong, D. G. (1985b). Insulin and glucose metabolism in sheep fed on driedgrass or ground, maize-based diets. British Journal of Nutrition 54, 459-471.

Johnson, D. E., Johnson, K. A. \& Baldwin, R. L. (1990). Changes in liver and gastrointestinal tract energy demands in response to physiological workload in ruminants. Journal of Nutrition 120, 649-655.

Landis, K. M., Goetsch, A. L., Forster, L. A. Jr \& Brake, A. C. (1989). Sites of digestion in beef steers fed bermudagrass hay and supplemented with high-nitrogen feeds alone or with tallow. Archives of Animal Nutrition 40, 387-401.

Lindsay, D. B. (1993). Making the sums add up - the importance of quantification in nutrition. Australian Journal of Agricultural Research 44, 479-493.

Martin, S. K. \& Hibberd, C. A. (1990). Intake and digestibility of low-quality native grass hay by beef cows supplemented with graded levels of soybean hulls. Journal of Animal Science 68, 4319-4325.

McCollum, F. T. \& Horn, G. W. (1990). Protein supplementation of grazing livestock: a review. Professional Animal Scientist 6, 1-6.

McLean, J. A. (1972). On the calculation of heat production from open-circuit calorimetric measurements. British Journal of Nutrition 27, 597-600.

Mineo, H., Yasuda, T., Akiyama, M., Oyamada, T., Kato, S. \& Ushijima, J. (1991). Effect of feeding on hepatic and portal blood flow in sheep. Small Ruminant Research 5, 181-186.

National Research Council (1984). Nutrient Requirements of Beef Cattle, 6th ed. Washington, DC: National Academy Press.

Reynolds, C. K., Huntington, G. B., Tyrrell, H. F. \& Reynolds, P. J. (1988). Net metabolism of volatile fatty acids, D-beta-hydroxybutyrate, nonesterified fatty acids, and blood gases by portal-drained viscera and liver of lactating Holstein cows. Journal of Dairy Science 71, 2395-2405.

Statistical Analysis Systems (1985). SAS User's Guide: Statistics. Cary, NC: SAS Institute, Inc.

van der Walt, J. G. (1993). Nitrogen metabolism of the ruminant liver. Australian Journal of Agricultural Research 44, 381-403.

Webb, K. E. Jr \& Bergman, E. N. (1991). Amino acid and peptide absorption and transport across the intestine. In Physiological Aspects of Digestion and Metabolism in Ruminants, pp. 111-128 [T. Tsuda, Y. Sasaki and R. Kawashima, editors]. New York: Academic Press.

Weekes, T. E. C. (1991). Hormonal control of metabolism. In Physiological Aspects of Digestion and Metabolism in Ruminants, pp. 183-200 [T. Tsuda, Y. Sasaki and R. Kawashima, editors]. New York: Academic Press.

Williamson, D. H. \& Mellanby, J. (1974). D-( $\beta$ )-3-Hydroxybutyrate. In Methods of Enzymatic Analysis, vol. 4, pp. 1836-1839 [H. Bergmeyer, editor]. New York: Academic Press.

Yen, J. T., Nienaber, J. A., Hill, D. A. \& Pond, W. G. (1991). Potential contribution of absorbed volatile fatty acids to whole-animal energy requirement in conscious swine. Journal of Animal Science 69, 2001-2012. 